いる。次に Fig. 4 に示すように3 令拗虫からの試験で は低湿度と高湿度の生育率・羽化率の差は大きくなり， 低湿度がヒメアカホシテントウの生育および羽化に影鹤 をもたらしていることが惩められた。またこの試験から 適湿は70〜90\% RH と思われるが，80\%以上の高湿度 の場合はカビの発生, カボチャの腐敗などが晃られるた め，奏用的には70〜80\% RH であろう。
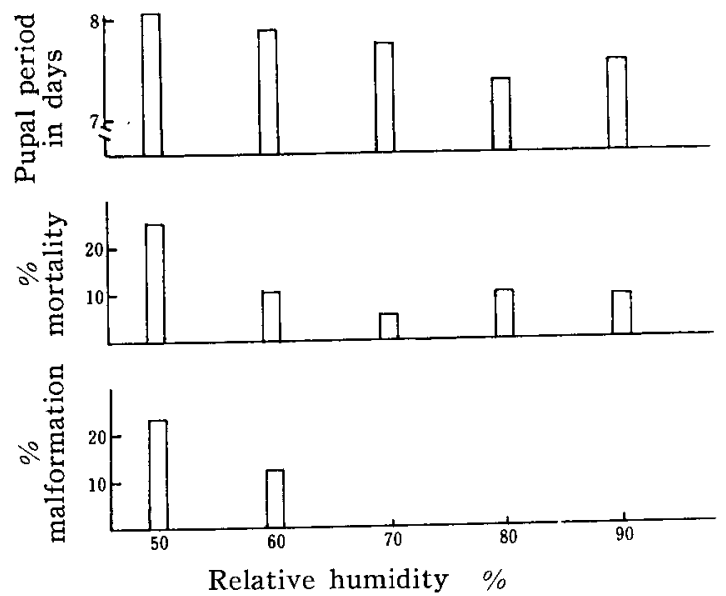

Fig. 3. Effect of relative humidity during pupal period on the development of C. kuwanae

結

論

以上の試験の結果からとメアカホシテントウの羽化率 に及ぼす要因すなわち，母虫，日長，慨の品質，密度効

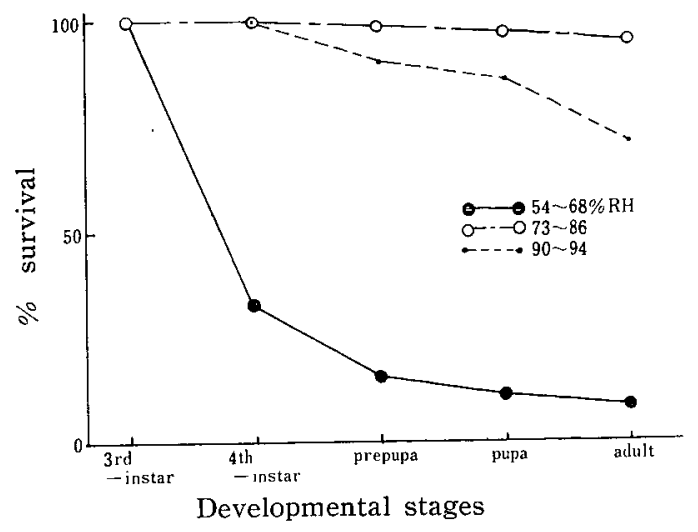

Fig. 4. Survival curves of C. kuwanae from the 3rd instar larvae reared under the different relative humidity

果にはほとんど影響されていないと舁われる。 Hodek (1958), Sethi (1964) によるアブラムシ捕食性テント ウムシでは，湿度による生育，羽化はほとんど影響され ていないことが報告されている。しかし本試験の結果, かなり影響を受けていることが明らかになった。なお， ヒメアカホシテントウの羽化に及ぼす各種要因について の影響は未知の点があると思わ㧈，今後の研究にまたね ばならない。

\section{引用 文 献}

1) Hodek, I. (1958) Acta. Soc. ent. jugosl. 55: 121 141. 2) Sethi, S. L., and Atwal, A.S. (1964) Indian. J. agric. Sci., 34: 166 171.

$$
\begin{aligned}
& \text { カンキッ園の捕食性名二の種類之分布 } \\
& \text { 田非学・井上，晃一（果樹試験場口之津支場） }
\end{aligned}
$$

\title{
Fauna and distribution of predacious mites on tree crown in the citrus area of the southern part of Japan
}

\section{Manabu TANAKA and Kouichi INoue (Kuchinotsu Branch, Fruit Tree Research Station)}

In the citrus area of the southern part of Japan, five species of predacious mites were found; Amblyseius largoensis (Muma), Amblyseius sp., Agistemus exsertus González-Rodríguez, Agistemus terminalis (Quayle) and Anystis sp.. A. largoensis and A. terminalis were dominant species. $A$. largoensis was found numerous especially in unsprayed grove. Distribution of $A$. largoensis on citrus tree crown was investigated. It was found that this predacious mites were abundant at lower inside parts of tree crown in contrast with the fact that the citrus red mite, Panonychus citri (McGregor), has much wider distribution on tree crown.

カンキツ園に晃受けられる械食性ダニには，ハダ二類 の天敵として重要な種頝が含まれており，これまでにカ ブリダニ科およびナガヒシダ二科に属するもの，それぞ れ数種が Ehara (1958，1959，1962，1964）および森
ら（1964）によって義告されている。これら博食性ダ二 のなかでも，カブリダ二科のものは一般に種類が多いこ とが知られているので，今後力ンキツ園で探索される未 知天敵のなかには有望な種類が存在する可能性も考えら 
れる。

したがって，著者らは八ダ二類の天敵として，有力な ものを見いだし，利用するために，暖地カンキツ園の捕 食性ダ二の種類と, その樹内分布について一部調查した ので報筶する。
報筅に先立ち，捕食性ダ二の分類，同定について，種 々ご指導をいただき，かつ標本の一部を同定して下さっ た鳥取大学教㴰学部の江原昭三教授，また捕食性ダ二の 採集に協力していただいた山口県荻村橘試駼場の野原啓

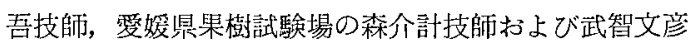

第 1 表 カンキツ園に打ける捕食性ダニの種類

\begin{tabular}{|c|c|c|c|c|c|c|c|c|}
\hline & & & & 捕 食 性 & 多 $=0$ & 種 類 & & \\
\hline 集 & 寄生植物 & 採集年月日 & 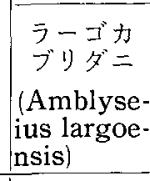 & $\begin{array}{l}\text { カブリ } \\
=の \\
=の \text { 種 } \\
\text { (Ambly- (Aeius 属) }\end{array}$ & 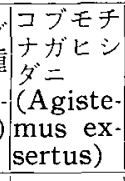 & $\begin{array}{l}\text { ケボソナ } \\
\text { ガヒシダ } \\
=\overline{\bar{A}} \\
\text { (Agiste- } \\
\text { mus ter- } \\
\text { minalis) }\end{array}$ & 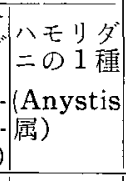 & 倩 洘 \\
\hline $\begin{array}{lllll}\text { 山口県 } & \text { 萩 } & \text { 市 } & \text { 江 } \\
\text { 山口抄 } & \text { 萩 } & \text { 市 } & \text { 山 } & \text { 田 } \\
\text { 山口県 } & \text { 萩 } & \text { 市 } & \text { 上 } & \text { 野 }\end{array}$ & $\begin{array}{c}\text { 夏柑 成木 } \\
" 1 \\
\prime\end{array}$ & $\begin{array}{l}\text { 1971. } 9.13 \\
1971.9 .13 \\
1971.9 .14\end{array}$ & (1) & & & 0 & 0 & $\begin{array}{l}\text { 無散布 } \\
\quad " \\
\text { 少散布 }\end{array}$ \\
\hline 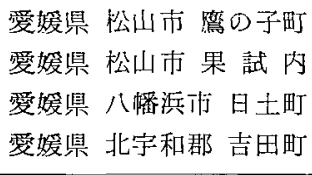 & $\begin{array}{l}\text { 普通温州战木 } \\
\text { 普通温州若木 } \\
\text { 予枯成木 } \\
\text { 夏榑成木 }\end{array}$ & $\begin{array}{l}\text { 1971. } 9.16 \\
1971.9 .15 \\
1971.9 .16 \\
1971.9 .17\end{array}$ & $\begin{array}{l}0 \\
0\end{array}$ & & 0 & $\begin{array}{l}0 \\
0\end{array}$ & 0 & $\begin{array}{l}\text { 無散布 } \\
\text { " } \\
\text { " } \\
\text { " }\end{array}$ \\
\hline $\begin{array}{c}\text { ·福岡県久留米材野菜試内 } \\
\text { " } \\
\text { " } \\
\text { " } \\
\text { " } \\
\text { " } \\
\text { " } \\
\text { " } \\
\text { " } \\
\text { " } \\
\text { " } \\
\text { " } \\
\text { " } \\
\text { " }\end{array}$ & 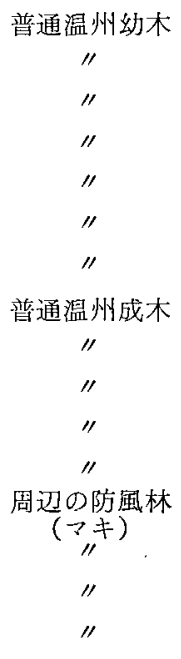 & $\begin{array}{ll}1971 . & 7.5 \\
1972 . & 2.8 \\
1972 . & 4.28 \\
1973 . & 1.25 \\
1973 . & 2.14 \\
1973 . & 2.23 \\
1973 . & 3.20 \\
1972 . & 6.20 \\
1972 . & 7.14 \\
1972.10 .2 \\
1973.2 .5 \\
1973.2 .15 \\
1972.7 .14 \\
1972.9 .22 \\
1973.2 .5 \\
1973 . & 3.20\end{array}$ & $\begin{array}{l}0 \\
0 \\
0 \\
0 \\
0 \\
0\end{array}$ & 0 & 0 & $\begin{array}{l}0 \\
0 \\
0 \\
0\end{array}$ & & $\begin{array}{l}\text { 少散布 } \\
\text { " } \\
\text { " } \\
\text { " } \\
\text { " } \\
\text { " } \\
\text { " } \\
\text { " } \\
\text { " } \\
\text { " } \\
\text { " } \\
\text { 無散布 } \\
\text { " } \\
\text { " } \\
\text { " }\end{array}$ \\
\hline $\begin{array}{c}\text { 福岡県 久留米书 草野町 } \\
\text { " } \\
\text { " } \\
\text { " } \\
\text { " } \\
\text { " } \\
\text { " }\end{array}$ & 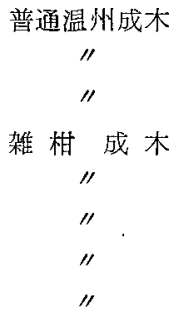 & $\begin{array}{l}1971.7 .6 \\
1972.10 .5 \\
1972.10 .30 \\
1972.6 .15 \\
1872.7 .27 \\
1972.8 .17 \\
1972.9 .25 \\
1972.10 .30\end{array}$ & & & 0 & $\begin{array}{l}0 \\
0 \\
0 \\
0 \\
0 \\
0 \\
0 \\
0\end{array}$ & & $\begin{array}{l}\text { 慣行散布 } \\
\text { ”: } \\
\text { " } \\
\text { 少散布 } \\
\text { " } \\
\text { " } \\
\text { " } \\
\text { " }\end{array}$ \\
\hline $\begin{array}{l}\text { 大分県 国 東 町 小 原 } \\
\text { 大分県 国東町 上治郎丸 }\end{array}$ & $\begin{array}{l}\text { 夏 柑 成 木 } \\
\text { 普通温州成木 }\end{array}$ & $\begin{array}{l}\text { 1973. } 2.14 \\
\text { 1973. } 2.14\end{array}$ & $\begin{array}{l}0 \\
0\end{array}$ & & & 0 & & $\begin{array}{l}\text { 無散布 } \\
\text { 少散布 }\end{array}$ \\
\hline $\begin{array}{l}\text { 鹿児島県西之表市 } \\
\text { 鹿児島県頴 娃 町 }\end{array}$ & $\begin{array}{l}\text { 夏柏 成木 } \\
\text { ポンカン成木 }\end{array}$ & $\begin{array}{ll}1972 . & 7.21 \\
1973 . & 3.19\end{array}$ & $\begin{array}{l}0 \\
0\end{array}$ & & & & & $\begin{array}{l}\text { 無散布 } \\
\text { 少散布 }\end{array}$ \\
\hline
\end{tabular}


技師に深謝の意を表する。

\section{調查方 法}

\section{1. 捕食性ダ二の種類}

1971年～73年に山口県萩市，愛䐘佰下，大分罧国東町，

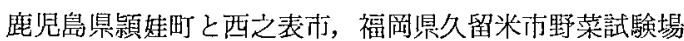
内と草野町のカンキッ園から捕食性ダ二を採集した。

\section{2. 捕食性ダ二の樹内分布}

1972年 6 月～10月に野菜試験場队 の 18年生普通温州 (調疽樹 4 本)について，1樹を㹝位別，上中下の高さ， 内外（中位部と下位別）の計 20 力所に区別した。 1 力所 加10枚，1樹あたり200枚の葉について，1葉ごとに诚 食性ダ二数と，ミカン八ダ二の生息数を発育段階別に調 查した。

\section{結果および考察}

カンキツ園の捕食性ダニの種類について調查した結果 は第 1 表に示したとおりである。カブリダニ科ではラー ゴカブリダニAmblyseius largoensis (Muma)がほとん ぞ主体を占めた。一方，ナガヒシダニ科では，コブモチナ ガヒシダニAgistemus exsertus González-Rodríguez
とケボソナガヒシダニ Agistemus terminalis (Quayle) の 2 種が見られ，後者の種が前者より分布範囲がはるか に広い傾向を示した。

ラーゴカブリダニは山口県, 愛媛県, 福岡県, 大分 県，鹿児島県などの調查を実施した各県のカンキッ園の なかで，特にヤノネカイガラムシや他のカイガラムシ類 が多発し：ミカン八ダ二の密度が低い薬剤無散布園に生 息数が多く，また，冬季のマシン油乳凪を主体とした防 除園でも多く見受けられた。

ケボソナガヒシダニも，かなり普遍的な種であり，本 種は慣行散布園にも度々見かけられた。

なお，カンキツ園周辽の防風林のマキにラーゴカブリ ダニとケボソナガヒシダニがかなり寄生していることが 確認された。マキの場合はこれまで八ダ二類の発生が見 られていないので，こ机ら捕食性ダニはマ,キについてい るカイガラムシ類を捕食しているものと思われる。

以上のようにカンキッ園には今回，ラーゴカブリダニ やケボソナガヒシダニをはじめ，他にコブモチナガヒシ ダニ，ハモリダニの1種およびカブリダニの1種など, 5 種類の捄食性ダ二を認めることができた。その内，カ ブリダニ科ではラーゴカブリダニが圧倒的に多く，他の

第 2 表 ラーゴカブリダニ，ケボソナガヒシダニとミカン八ダニの樹内分布（平均 1 葉あたり生息数）

\begin{tabular}{|c|c|c|c|c|c|c|c|c|}
\hline \multirow{3}{*}{ 調查月日 } & \multirow{3}{*}{$\begin{array}{c}\text { 調查樹 } \\
\text { No. }\end{array}$} & \multirow{3}{*}{ 調 査 項 目 } & \multicolumn{3}{|c|}{ 樹 } & \multicolumn{2}{|c|}{ 阝 位 } & \multirow{3}{*}{ 備 考 } \\
\hline & & & \multirow{2}{*}{ 上位部 } & \multicolumn{2}{|c|}{ 中 位 部 } & \multicolumn{2}{|c|}{ 下 部 位 } & \\
\hline & & & & 外 側 & 内 側 & 外 側 & 内 側 & \\
\hline \multirow{5}{*}{ 1972. 6.20} & \multirow{5}{*}{ I } & ミカン八ダ二郋 & 5.40 & 3.53 & 7.73 & 3.25 & 8.05 & \multirow{5}{*}{ 薄昙 } \\
\hline & & " 幼若虫 & 2.10 & 1.08 & 4.90 & 0.93 & 2.50 & \\
\hline & & 雌成虫 & 0.13 & 0.23 & 0.75 & 0.13 & 0.68 & \\
\hline & & ラーゴカブりダニ & 0 & 0 & 0 & 0.08 & 0.33 & \\
\hline & & ケボソナガヒシ ダニ & 0 & 0 & 0 & 0 & 0.05 & \\
\hline \multirow{5}{*}{ 1972. 6.20} & \multirow{5}{*}{ II } & ミカン八ダ = 卵 & 3.48 & 3.80 & 5.78 & 1.95 & 2.48 & \multirow{5}{*}{ 薄雲 } \\
\hline & & " 幼若中 & 1.95 & 1.03 & 1.80 & 0.48 & 0.43 & \\
\hline & & 踓成虫 & 0.20 & 0.33 & 0.58 & 0.15 & 0.20 & \\
\hline & & ラーゴカブリダニ & 0 & 0.08 & 0 & 0.25 & 0.30 & \\
\hline & & ケボソナガヒシダニ & 0 & 0 & 0 & 0 & 0 & \\
\hline \multirow{5}{*}{ 1972. 6.14} & \multirow{5}{*}{ III } & ミカン八ダ二郋 & 4.20 & 3.53 & 3.15 & 0.63 & 2.65 & \multirow{5}{*}{ 唶 } \\
\hline & & " 幼若虫 & 1.02 & 1.23 & 1.98 & 0.58 & 1.23 & \\
\hline & & " 睢成虫 & 0.30 & 0.30 & 0.48 & 0.13 & 0.25 & \\
\hline & & ラーゴカブリダ & 0.10 & 0 & 0 & 0.08 & 0.18 & \\
\hline & & ケボソナガヒシダニ & 0 & 0 & 0 & 0 & 0 & \\
\hline \multirow{5}{*}{1972.6 .14} & \multirow{5}{*}{ IV } & ミカン八ダ = 卵 & 0.73 & 1.10 & 1.68 & 1.08 & 1.25 & \multirow{5}{*}{ 晴 } \\
\hline & & " 奻若虫 & 0.10 & 0.40 & 0.90 & 1.13 & 0.73 & \\
\hline & & ", 辡成虫 & 0.05 & 0.03 & 0.18 & 0.10 & 0.28 & \\
\hline & & ラーゴカブリダニ & 0 & 0.03 & 0.05 & 0.05 & 0.18 & \\
\hline & & ケボソナガヒ シダニ & 0 & 0 & 0 & 0 & 0.03 & \\
\hline
\end{tabular}


カブリダニはきわめて少なかったが，この点は菻(1964) が愛媛県下で調查した結果とよく一致している。

つぎ捕食性ダニのなかで，優占種と考えられるう一 ゴカブリダニ，ケボソナガヒシダニの樹内分布を 6 月〜

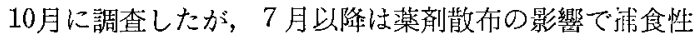
ダニの密度が著しく娍少したため，6月の調查結果につ いてだけ符 2 装に示した。

その結果，ラーゴカブリダニは樹内の下位部内側のう す暗いところに多い傾问が兒られたが，ケボソナガヒシ ダニの場合は生息密度がきわめて少なかったため，明ら かな結果が得られなかった。また，ラーゴカブリダニと ミカンハダ二の樹内分布の関係について見ると，ラーゴ カブリダニの生息部位はミカンハダ二の密度の多少とは 関係がないと思われる。すなわち，ラーゴカブリダニの 生息部位が樹内下位部の内侽に比較的集打していること から、いったんミカン八ダニの密度が离くなり，ハダニが 樹冠全体に分布してしまった場合，ラーゴカブリダ二の 天敵としての抑制効果はあまり期待できないと考えられ る。しかし、ミカン八ダニの発生初期のような低密度の 場合には，ラーゴカブリダニと八ダニの生息部位が一致 する可能性も火きいので，有効に㗢くものと推測される。
ラーゴカブリダニの有效性については，森 (1964) が 本種の発生はミカン八ダ二の多発錐で少なく，少発園で 多いこと，八ダ二の低密度時にはその增殖を㧕制する才 が大きいこと，またハダ二のほかに，2，3のカイガラム シの若令幼虫を捕食することなどを㫰告している。

以上のことから，ラーゴカブうダニはカンキツ畦の八 ダニ類の天敵として, 有望だと考えられるので，今後, 本種をはじめ，ケボソナガヒシダニなどの捕食性ダニの 天敵としての役制を語洒し，有效な利用法について検討 したい。しかし，現状柱これら捕食性ダニが農葙散布の 影響を受け，ほとんど活動の場を与えられていないので， まず，薬凨の使い庁や環境に多様性をもたせるよう工夫 して，天敵の保護利用を積極的にはかることが必要であ る。

\section{引用 文 献}

1) Ehara, S. (1958) Annot. Zool. Jap. 31: 53 57. 2 ) Ehara, S. (1959) Acarologia 1: 285 295. 3) Ehara, S. (1962) Japan Appl. Ent. Zool. 6: 53 60. 4) Ehara, S. (1964) Annot. Zool. Jap. 37：226～232. 5) 㷊介 計 (1964) 愛瑷県果試研報告 $4: 43 \sim 54$.

\section{高度精製マシン油乳剂の春季散布によるミカンの薬害}

山本一栄 一(宮崎鼠総合農業壾験埸)

緒 言

マシン渵乳剤は各種害虫に対する幅広い殺虫スペクト ルを有し，人畜珘性や魚貝類に対する珘性は低く，他の 殺虫, 殺ダニ剤の一部にみられるような効力低下もなく， 天敵への影響も少ないなど，㖘薬としてすぐれた性質を もっている。反面，本剂は植物に浆害のでやすい欠点が あり, 通常, 冬季の限られた時期のみの使朋にとどまっ ていた。

近年，油分97\%でスルホン価，平圽分子量，粘度など， 従来の95\%製品のそ狆より小い高度精製マシン油乳剂 が開発され，すでに一部のミカン栽培地帯では発武前の 3月や生育期の散版がとりいれられている。しかしなが ら, 九州における高度精製マシン油乳剤の冬季以外の時 期での使用については，末解決な点が残されており，今 回は発芽前（3月）の散布が，温州ミカンの樹体に及ぼ 寸影響（薬害）について若广の知見を得たので，その概 要を報告する。

\section{試 験 方 法}

試験 1 ：供試樹には17年生普通温州11樹を用い高度精

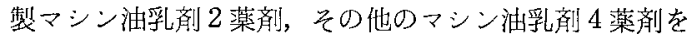
$25 ， 50 ， 100 ， 200$ 倍に稀釉して処理した。1968年 3 月15 日(くもり，13〜 $15.2^{\circ} \mathrm{C}$ ) に，発芽 15 日前の各樹文.ら， 比較的均一な結果母枝 $(10 \sim 20 \mathrm{~cm})$ を多数選定し，それ ぞれの薬波に10秒間浸漬した。1薬昘の処理枝数は各樹 で 1 〜 反覆し，合計 25 枝を供試した。

試験 2 : 早生温州，普通温州いずれも10年生 5 樹を用 いた。高度精製マシン油乳剤 5 葲剂，その他のマシン油 乳剤 1 薬剤を 40，60，100 倍に稀粈し，1972年 3 月15日

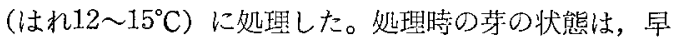
生温州，発芽直澈～発牙はじめ，普通温州，発芽約 7 日 前であった。処理にあたっては各樹から結果母枝を 4 本 以上つけた鉛筆大の枝を多数設定し，それぞれの薬液に

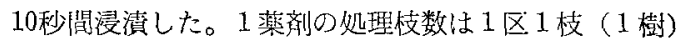
とし 3 反覆（ 3 樹）した。

\section{結果および考察}

試験 1 : 処理後, 各区に油浸症状（以下油浸）が葉颜 に多られたが，その程度は薬鼡によってかなり差異があ り，また，高濃度の場合に著しい㑯向にあった。この油 